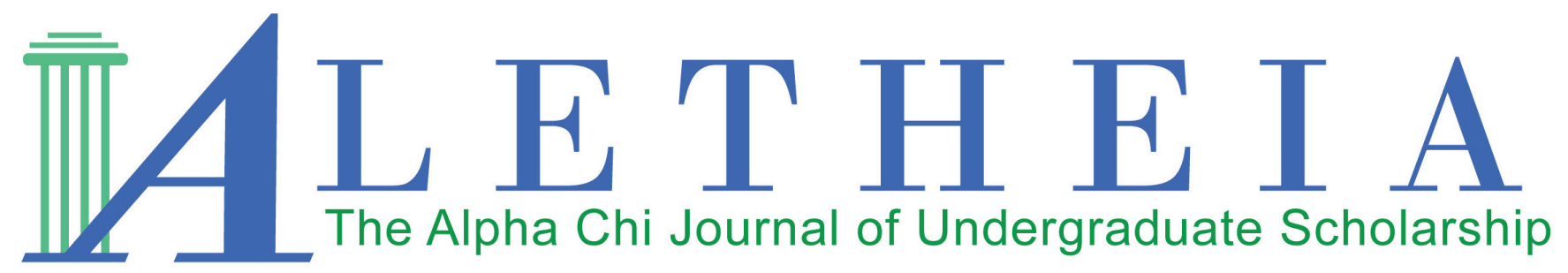

Volume 3 | Issue 2 | 2018

\title{
Collective Guilt: Exploring Antisemitism, Knowledge, and Fear in the Nazi Era
}

\author{
Madeline Moler \\ Southwest Baptist University \\ Missouri Gamma
}

Vol. 3(2), 2018

Title: Collective Guilt: Exploring Antisemitism, Knowledge, and Fear in the Nazi Era

DOI:

ISSN: $2381-800 \mathrm{X}$

Keywords: collective guilt, Nazi Germany, Holocaust, antisemitism, Third Reich

This work is licensed under a Creative Commons Attribution 4.0 International License.

Author contact information is available from tlindblom@alphachihonor.org or kvosevich@alphachihonor.org

\section{Aletheia-The Alpha Chi Journal of Undergraduate Scholarship}

- This publication is an online, peer-reviewed, interdisciplinary undergraduate journal, whose mission is to promote high quality research and scholarship among undergraduates by showcasing exemplary work.

- Submissions can be in any basic or applied field of study, including the physical and life sciences, the social sciences, the humanities, education, engineering, and the arts.

- Publication in Aletheia will recognize students who excel academically and foster mentor/mentee relationships between faculty and students.

- In keeping with the strong tradition of student involvement in all levels of Alpha Chi, the journal will also provide a forum for students to become actively involved in the writing, peer review, and publication process.

- More information can be found at www.alphachihonor.org/aletheia. Questions to the editor may be directed to tlindblom@alphachihonor.org or kvosevich@alphachihonor.org.

Alpha Chi is a national college honor society that admits students from all academic disciplines, with membership limited to the top 10 percent of an institution's juniors, seniors, and graduate students. Invitation to membership comes only through an institutional chapter. A college seeking a chapter must grant baccalaureate degrees and be regionally accredited. Some 300 chapters, located in almost every state, induct approximately 11,000 members annually. Alpha Chi members have been "making scholarship effective for good" since 1922. 


\title{
Collective Guilt: Exploring Antisemitism, Knowledge, and Fear in the Nazi Era
}

\author{
Madeline Moler \\ Southwest Baptist University \\ Missouri Gamma
}

\begin{abstract}
This paper discusses the culpability of the majority of Germans who did not actively participate in the Holocaust nor actively oppose it. Germany had a long history of antisemitism before the Third Reich, at times more conspicuous than at others. Some moral leaders such as ministers supported the regime, blurring the distinction between right and wrong. There are Germans who say they knew nothing of gas chambers and crematoriums while others say they knew of them from the beginning. To further complicate matters, whole families feared punishment for the crime of one member. The purpose of this paper is to weigh these and other factors and to contribute to the understanding of collective guilt, which holds the majority responsible.
\end{abstract}

Keywords: collective guilt, Nazi Germany, Holocaust, antisemitism, Third Reich

Approximately six million Jews were killed under the Third Reich and someone had to be held responsible. ${ }^{1}$ The Nuremberg trials brought legal justice to many of the perpetrators, and even today the occasional Nazi is tried in court. However, are only those who actively participated in the killing responsible for the genocide? Though they did not give the order, pull the trigger, or pour in the gas, the wider German public voted Hitler into office, espoused antisemitism, ${ }^{2}$ and watched in si-

1 "Documenting Numbers of Victims of the Holocaust and Nazi Persecution." United States Holocaust Memorial Museum. Accessed November 02, 2017.

2 I will use the spelling "antisemitism" as opposed to "anti-Semitism" as the latter denotes a racial or genetic differentiation between Jews and other peoples. While Judaism is a distinct religion and people group, there are no genetic or racial differences, and implying there are provides a justification for racist attitudes towards them (The Holocaust Chronicle, 2000). The spelling antisemitism denies this distinct biological variation and thus denies the justification for racism. Many scholars have begun to adopt this spelling, Susannah Heschel and Yehuda Bauer argue that there is no such thing as "Semitism," and that "anti-Semitism" was coined by Wilhelm Marr to "express their hatred of the Jews in secular, rather than religious terms," (Bergen, 1994). lence as millions were murdered. The collective guilt of the German people has been a controversial subject for decades, one that is exceedingly complex. The Allies were forced to determine who was morally and legally responsible for the actions taken by their country. Many Germans claim they did not know that the mass murder was taking place at all. Some historians believe that only those who played an active role were guilty, while others count those who stood silently by just as guilty as those actively involved. Had the Germans of the Nazi era spoken out against the Final Solution, the Holocaust may have been averted. There are several examples of successful protests against the persecution of other groups in Nazi Germany, of the truth leaking out from the east, and of a general indifference towards the Jewish population. Alternatively, a strong sense of fear loomed over those who did not wholeheartedly agree with the Nazis. Out of those who dared to object, there are countless examples of not only individuals facing the consequences, but their families as well. As some Germans of the time suggest, perhaps these bystanders got lost in the frenzy or turned off their minds to the idea of genocide. Dietrich Bonhoeffer, an anti-Nazi minister, said,

"Who would deny that the German, again and again, has done his utmost in bravery, risked 
his life obeying orders, following his calling, or doing his work... But, in doing so, he has not understood the world; he had not anticipated that his willingness to subordinate his ego, and to risk his life for his calling can be abused for evil.... Thus, the German never grasped a decisive and fundamental idea: the necessity to act freely and responsibly even if it impaired his work and his calling." 3

Bonhoeffer seems to hold that the Germans at large were lost in their culture and never learned that morality supersedes all other obligations. Legally, these ordinary German citizens were innocent. Morally, it is irresponsible to excuse their behavior. A moral obligation always stands, even when blurred and ignored by fear and hatred.

First, one must clarify the demographic discussed here. There is a difference between those who are obviously guilty - in other words, those who were involved specifically in the mass murder - and those who were not, who are the subject here. This includes the German population at large and the families of those directly involved in the killing. Secondly, to understand the climate of German society towards Jews, it is necessary to provide a brief history of antisemitism in Germany in the decades leading up to the Nazi era, as well as its place in the Church. Finally, determining what the German population knew about Nazi ideology and the Holocaust, and when they knew it, is essential to gauging their level of responsibility for the genocide.

In Germany and much of the world, antisemitism had largely been connected to Christianity, but this began to change after the Enlightenment. In the later years of the eighteenth-century, Jews did not enjoy equal rights in Prussia; it was during this time that Christian Wilhelm Dohm, a political and historical writer, began "demand[ing] full equality." He believed that the Jews were corrupt, but only because they had been denied their rights as citizens and as people; thus, granting those rights would remedy their crookedness. ${ }^{4}$ Other academics, in general, welcomed Dohm's views and agreed that his heart was in the right place. However, Rotteck's and

\footnotetext{
${ }^{3}$ Vogt, Hannah. The Burden of Guilt: A Short History of Germany, 1914-1945. New York: Oxford University Press, 1964. ${ }^{4}$ Low, Alfred D. Jews in the Eyes of the Germans. Philadelphia, PA: Institute for the Study of Human Issues, 1979. 31-33.
}

Welcker's Encyclopedia of Political Science (1834) records that despite this praise, the notion of granting full rights was "absurd" to the general public. Some critics believed that the only way Jews could make good citizens would be if they converted to Christianity, while others maintained that they were "foreigners and aliens." This idea set the tone that the only way to "bridge the gap" between Jews and Germans was if the Jews "were prepared to abandon their religious identity, shed their cultural heritage, and, in effect, commit suicide as a people." ${ }^{5}$ Under Napoleon's rule, Germany experienced a temporary warming towards Jews, only to be pushed back by book burnings and chants of "Woe to the Jews!"6 Johann Gottlieb Fichte, a philosopher whose ideas would later be used by Nazis, was also writing at this time. Though he had antisemitic tendencies, he argued that Jews should have natural human rights and were not the core of Germany's issues. ${ }^{7}$

During the Romantic era, "the emotional and intellectual climate...ran counter to the spirit of social and political progress in the field of German-Jewish co-existence." ${ }^{8}$ Antisemitism grew across all socio-economic classes; however, this did not stop Jews from participating in the drive to unite Germany. ${ }^{9}$ After the revolutions of 1848 and 1849, there arose a trend of Jews increasingly contributing to and engaging in German culture and thought. ${ }^{10}$ Many assimilated Jews slowly gained more rights until 1869, when Otto von Bismarck signed a law declaring that Jews would hence be considered legally equal. ${ }^{11}$ Despite the progress, in the 1870 s, democratic liberalism lost sway and antisemitism "grew by leaps and bounds, intellectually, socially, and politically." ${ }^{\prime 2}$ Popular historian and publicist Heinrich von Treitschke strongly influenced the political education of his students and made antisemitism "fashionable once again." "13 Another philosopher who greatly influenced Nazi ideology was Friedrich Nietzsche. Low argues that Nietzsche was not antisemitic, but that such ideas were applied to his thoughts on the Aryan race and superiority

\footnotetext{
${ }^{5}$ Low. Jews in the Eyes of the Germans. 1979. 34

${ }^{6}$ Low. Jews in the Eyes of the Germans. 1979. 66, 114-115.

7 Low. Jews in the Eyes of the Germans. 1979. 143, 145-146.

8 Low. Jews in the Eyes of the Germans. 1979. 214.

${ }^{9}$ Low. Jews in the Eyes of the Germans. 1979. 255.

${ }^{10}$ Low. Jews in the Eyes of the Germans. 1979. 299, 307.

${ }^{11}$ Low. Jews in the Eyes of the Germans. 1979. 311.

${ }^{12}$ Low. Jews in the Eyes of the Germans. 1979. 359, 369.

${ }^{13}$ Low. Jews in the Eyes of the Germans. 1979. 3369.
} 
after he had died. ${ }^{14}$ In the socialist movement, many associated Judaism with negative and usurious economic policy, while others saw antisemitism as a positive step away from capitalism and toward a socialist utopia. ${ }^{15}$

In the 1870 s, Rudolf Virchow conducted a study that would solidify a racial understanding of Judaism. At this time, there was an anthropological trend towards observing internal racial characteristics — particularly skull measurements - and using complicated statistics in an attempt to reconstruct German pre-history. ${ }^{16}$ However, in order to gather enough data, the study needed large numbers of subjects. With only a few experts trained in how to take these measurements, it would have taken decades to gather reliable data. To circumvent this obstacle, the researchers simplified the process and lowered their standards so that people such as teachers would be able to record data. They did this by associating the skull lengths with hair, eye, and skin color and assigning those characteristics to racial types. ${ }^{17}$ The blonde type (blonde hair, white skin, blue eyes) and the brunette type (brunette hair, brown eyes, brown skin) were considered the two pure racial types, with all variations resulting from a mixed racial background of these two types. Blonde was associated with German and Nordic people, while brunette was linked to others such as Czech, Slav, Frank, and Jewish people. The blonde and brunette types were not races themselves, but external and easily identifiable indicators of race. ${ }^{18}$ After getting state support, Virchow and his team sent forms to teachers across the country with requests to record the number of students with each variation of the blonde and brunette types. The teachers were instructed to record the Jewish students separately so as not to disrupt the data, therefore requiring

\footnotetext{
${ }^{14}$ Low. Jews in the Eyes of the Germans. 1979. 380.

${ }^{15}$ Low. Jews in the Eyes of the Germans. 1979. 396, 401.

${ }^{16}$ Zimmerman, Andrew. "Anti-Semitism as Skill: Rudolf Virchow's Schulstatistik and the Racial Composition of Germany." Central European History (Brill Academic Publishers) 32, no. 4 (December 1999): 409. Academic Search Premier, EBSCOhost (accessed October 30, 2017). 412-413, 415-417.

${ }^{17}$ Zimmerman, Andrew. "Anti-Semitism as Skill: Rudolf Virchow's Schulstatistik and the Racial Composition of Germany." Central European History (Brill Academic Publishers) 32, no. 4 (December 1999): 409. Academic Search Premier, EBSCOhost (accessed October 30, 2017). 412-413. ${ }^{18}$ Zimmerman. "Anti-Semitism as Skill: Rudolf Virchow's Schulstatistik and the Racial Composition of Germany." 1999. 414.
}

the teachers to arrange the students based on race. This practice taught both teachers and students to look for these differences in relation to an individual's Jewishness. ${ }^{19}$

The study found that $32 \%$ of Germans were pure blonde and $14 \%$ pure brunette, while $11 \%$ of Jews were blonde and $42 \%$ brunette. Today this indicates that there is no racial uniformity among Jews or Germans, but at the time it was regarded as proof that they were separate races. The anthropologists had three explanations for the blond Jews: first that they began to look like the surrounding population as they assimilated, second that they mixed with the surrounding population as they assimilated, and third that there were two types of Jews - a common dark type and a rare blonde type. Virchow believed that those who were blonde were actually mixed and that as Jews married amongst themselves, they would 'purify' (become more brunette). ${ }^{20}$ Zimmerman argues that the study "gave racism [a] statistical, scientific, and practical basis," and a generation of Germans learned antisemitism as a skill- how to "perceive and classify race' - and laid the foundations for "racist, anti-Jewish ideology and politics." 21 This study went on to influence ideology such as Friedrich Nietzsche's, and more importantly taught Germans "tacit skills" for understanding race. They learned to "do" racism before they learned to "think" it and to "experience themselves in terms of whiteness and brownness and to recognize racial distinctions between 'Jews' and 'Germans." Zimmerman concluded that without these lessons, later "ideological tracts could not have made sense, and the practical regimes that would later so distinguish German anti-Semitism could not have been implemented." 22

In short, the Enlightenment dispelled religious antisemitism and replaced it with one based on economy and nationality (though nineteenth-century antisemitism was always there, sometimes hidden under the surface

\footnotetext{
${ }^{19}$ Zimmerman. "Anti-Semitism as Skill: Rudolf Virchow's Schulstatistik and the Racial Composition of Germany." 1999. 417-419.

${ }^{20}$ Zimmerman. "Anti-Semitism as Skill: Rudolf Virchow's Schulstatistik and the Racial Composition of Germany." 1999. 423.

${ }^{21}$ Zimmerman. "Anti-Semitism as Skill: Rudolf Virchow's Schulstatistik and the Racial Composition of Germany." 1999. 424, 426.

${ }^{22}$ Zimmerman. "Anti-Semitism as Skill: Rudolf Virchow's Schulstatistik and the Racial Composition of Germany." 1999. 427-429.
} 
of "social and cultural progress" 23 ). In literature and academia scholars gave antisemitism the appearance of logical and credible thought. ${ }^{24}$ In addition, the Jews were always classified with a sort of otherness, with native Germans insisting they were not German no matter how many assimilated. ${ }^{25}$ This concept was solidified and given scientific, racial context by Virchow's study. With the rapid rise of nationalism in Germany and the desire for a "strong, unitary, homogenous nation" came the desire for minorities such as the Jews to merge fully with the state or leave. Jews were not willing to give up their identity, and it was also about this time their own nationalist movement, Zionism, was developing. ${ }^{26}$ Despite all this, Jews did not "rationally expect" to lose their rights or be exiled, even at the climax of nineteenth-century antisemitism. An event like the Holocaust was completely unthinkable. ${ }^{27}$ Nevertheless, the nineteenth century readied Germany to accept a more radical antisemitism fifty years later.

In the early part of the twentieth-century, antisemitism continued to be common, if not blatantly or violently expressed. A "strong sense of insiders and outsiders" developed in which "Jews were often held up as the prime example of "the other." 28 Though most Jews were middle class, the focus was on the few wealthy Jewish businessmen who thrived during the economic crisis of the 1920s. This focus leads to a rise in hostility toward Jews, since they 'prospered' while the rest of the population suffered. Germans of every stripe shared these sentiments: "judges, army officers, conservative and radical right-wing politicians, Protestant and Catholic clergy, and teachers." ${ }^{29}$ In a 1923 letter, Bertha Pappenheim recorded incidents she witnessed of harassment and death threats to Jews. In the same letter, she describes how the Jews were understood to be cheating the rest of the nation by charging high prices or interest rates and going back on deals. Five years later, the Protocols of the Elders of Zion would find its way into circulation in Germany. Initially published in Russia, the Protocols were an alleged account of a meeting between the Jewish leaders from around the world to plan for the

\footnotetext{
${ }^{23}$ Low. Jews in the Eyes of the Germans. 1979. 409.

${ }^{24}$ Low. Jews in the Eyes of the Germans. 1979. 410.

${ }^{25}$ Low. Jews in the Eyes of the Germans. 1979. 411-412.

${ }^{26}$ Low. Jews in the Eyes of the Germans. 1979. 411-412.

${ }^{27}$ Low. Jews in the Eyes of the Germans. 1979. 410.

28 "Primary Sources: Weimar Society." Facing History and Ourselves. 2017. Accessed November 03, 2017.

29 "Primary Sources: Weimar Society." Facing History and Ourselves. 2017. Accessed November 03, 2017.
}

domination and enslavement of the rest of the world. ${ }^{30}$ These concepts grew in popularity as the German people became more and more frustrated with the economy and the Weimar Republic's inadequacy to fix it.

Propped up at the end of the First World War by the victorious countries, the Weimar government's issues began with its illegitimacy. After losing much of their industrial areas and footing the bill for the entire war, Germany's economy suffered hyperinflation and unemployment levels that reached $30.8 \%$ in $1932 .{ }^{31}$ The Nazi party, promising to end the chaos and violence that ran rampant, was a third option between the universally hated Weimar Republic and a much-feared Communist takeover. Furthermore, the Germans were attracted to the "Nazis' visionary ideology" and campaign for the return of Germany to glory. ${ }^{32}$ For example, in September of 1930 , the Nazi Party received $28 \%$ of the vote in the town of Osnabrück. ${ }^{33}$ On July 3, 1932, fourteen million people-over one-third of the population-voted for Adolf Hitler to become the Chancellor of Germany, an act which allowed his later consolidation of power. ${ }^{34}$

Determining responsibility for the Holocaust in part necessitates looking at Germans' perception of Hitler. Hubert Lutz was a German boy from Cologne about six years old at the time of Hitler's election. His father served as a "midlevel Nazi Party functionary.' ${ }^{35}$ He described Hitler as "loved and admired" and was portrayed as "a savior" in the early years of the Reich. "We felt he could do no wrong," and anything contrary was "[blamed] on the underlings." 36 In Dresden, Gertrud Sombart described a day when Hitler stayed at a hotel in town and a crowd gathered outside "screaming, 'We want to see our Führer!" hoping to get just a glimpse of him. Why was such a radical man so beloved? A young

\footnotetext{
30 "Primary Sources: Weimar Society." Facing History and Ourselves. 2017. Accessed November 03, 2017.

${ }^{31}$ Goldhagen, Daniel Jonah. Hitler's Willing Executioners: Ordinary Germans and the Holocaust. New York: Vintage Books, 1997. 86.

${ }^{32}$ Goldhagen. Hitler's Willing Executioners: Ordinary Germans and the Holocaust. 1997. 87.

${ }^{33}$ Panayi, Panikos. Life and Death in a German Town: Osnabrück from the Weimar Republic to World War Iand beyondnd. I.B Tauris, 2007. 37.

${ }^{34}$ Goldhagen. Hitler's Willing Executioners: Ordinary Germans and the Holocaust. 1997. 87.

${ }^{35}$ Johnson and Reuband. What We Knew: Terror, Mass Murder and Everyday Life in Nazi Germany. 2006. 141.

${ }^{36}$ Johnson and Reuband. What We Knew: Terror, Mass Murder and Everyday Life in Nazi Germany. 2006. 149.
} 
Berlin woman at the time, Ruth Hildebrand attributed Hitler's popularity to how quickly and effectively he was able the fix the country's economy. After Hitler came to power there was virtually no unemployment, food was cheaper, and wages increased. ${ }^{37}$ In an interview, Ernst Walters discussed how everyone was better off, there were new opportunities for young people, and even "the little guy was able to get something for himself," such as a new Volkswagen. ${ }^{38}$ Holocaust survivor Primo Levi received a letter from a Dr. T. H. who claimed that he was attracted to Hitler's "beautiful words" and his "one success after another." 39

Central to the ideas of Nazis and Hitler were their beliefs regarding the Jews. Maschmann recounted that they seemed "mysteriously menacing and anonymous" and an "active force for evil." Despite this, many Germans had close relationships with Jews, excluding them from the larger group. She claimed that no one addressed this contradiction of hating Jews but having Jewish friends, and suggested that part of the answer was that no one knew who exactly 'the Jews' were. Did it include "the baptized and the orthodox, Yiddish speaking second-hand dealers and professors of German literature, communist agents and First World War officers decorated with high orders, enthusiasts for Zionism and chauvinistic German nationalists...?"40 Thus the Nuremberg laws delineating who was Jewish and who was not were necessary to secure systematic, consistent, and widespread anti-Semitism. Maschmann did not read them because she did not wish to oblige herself to think about the unfairness of the laws. However, popular German anti-Semitism seemed to have its limits. According to Maschmann and others, Der Stürmer was only marginally accepted and believed to have crossed the line. ${ }^{41}$

Goldhagen believes that anti-Semitism had been ingrained in their culture for years and had only just

\footnotetext{
${ }^{37}$ Johnson, and Reuband. What We Knew: Terror, Mass Murder and Everyday Life in Nazi Germany. 2006. 191.

${ }^{38}$ Johnson, and Reuband. What We Knew: Terror, Mass Murder and Everyday Life in Nazi Germany. 2006. 206.

${ }^{39}$ Levi, Primo. The Drowned and the Saved. Translated by Raymond Rosenthal. New York: Random House, Inc., 1989. 176-177.

${ }^{40}$ Maschmann, Melita. Account Rendered: A dossier on my former self. Translated by Geoffrey Strachan. London: Abelard-Schuman, 1965. 40-41.

${ }^{41}$ Maschmann. Account Rendered: A dossier on my former self. 1965. 46-47.
}

began manifesting itself. His book Hitler's Willing Executioners has been met with much controversy; some praise his ardent and direct approach while many others criticize it. Browning, for example, suggests a possible double standard in Goldhagen's research regarding the treatment of Poles and Jews. ${ }^{42}$ Nevertheless, Goldhagen's work provides numerous examples of widespread antisemitism and a point with which to compare other conclusions on the collective guilt of the German people. According to Goldhagen, antisemitism adopts whatever is culturally prominent at the time, such as a form of Social Darwinism. ${ }^{43}$ Thus it can be determined that Germany had a long history of underlying antisemitism that the Nazis simply exposed. Goldhagen also agreed with Maschmann and added that the perceived threat was, in reality, a hallucination perpetuated by the economic stereotypes. However, the perception that it was reality led to the general approval of genocide. ${ }^{44}$ To support his assertion, he points to how rapidly anti-Jewish activity began after Hitler's election. That same year, many towns forbade Jews from entering public places, expelled them from professional groups, and ostracized them from colleagues. These actions were not limited to the 'mindless masses'; businessmen, medical professionals, and intellectuals participated and supported it as well. ${ }^{45} \mathrm{In}$ Osnabrück alone there were "massive demonstrations" and 25,000 people attended an event to hear speakers on "the Jewish problem." The people's enthusiasm was so great that Nazi officials outlawed these sorts of actions. ${ }^{46}$ Furthermore, the courts upheld the discrimination, and so fierce was their conviction that "leading Nazis... chastised judges for having violated the law in their rampant eliminationist ardor." 47

The parents of German children who grew up in Nazi Germany also shaped the views of their children. Maschmann explained that the adults 'knew' about the

\footnotetext{
${ }^{42}$ Browning, Christopher. "Afterward," Ordinary Men. New York: Harper Collins, 1998. 212-213.

${ }^{43}$ Goldhagen. Hitler's Willing Executioners: Ordinary Germans and the Holocaust. 1997. 39-40.

${ }^{44}$ Goldhagen. Hitler's Willing Executioners: Ordinary Germans and the Holocaust. 1997. 89.

${ }^{45}$ Goldhagen. Hitler's Willing Executioners: Ordinary Germans and the Holocaust. 1997. 96.

${ }^{46}$ Goldhagen. Hitler's Willing Executioners: Ordinary Germans and the Holocaust. 1997. 94-95.

${ }^{47}$ Goldhagen. Hitler's Willing Executioners: Ordinary Germans and the Holocaust. 1997. 97.
} 
'true menacing nature' of the Jews, and their children ad opted this view as natural and correct. She learned from her parents that "one could have anti-Semitic opinions without them interfering with relations with individual Jews." She attributed her ability to "dedicate body and soul to an inhuman political system, without this giving me doubts about my own individual decency." ${ }^{48}$ Adults were pushed to keep children in the dark regarding the disappearance of their Jewish neighbors. ${ }^{49}$ Many whose interviews are featured in Johnson's What We Knew expressed opinions similar to those of their parents. To what extent could these children who were brought up thinking that Nazi ideology was right be held responsible as participants and facilitators once they were older?

Once Nazism took hold of the country, many continued to support it. Melita Maschmann describes the joy she felt at a BDM (the girls' division of the Hitler Youth) rally in 1938: "The feeling of being young, belonging together, of understanding and loving one another in all the variety of our characters, which resulted from our different origins - and above all the feeling that we had a common task - how should it not fill us with overwhelming joy?" ${ }^{50}$ Hubert Lutz said in an interview that denunciations gave people a sense of "power" and "patriotic duty." 51 The Nazis restored Germans' sense of national pride and community, something they had lost in WWI.

However, not all supported the new regime. Lutz also described an incident in which a teacher reprimanded him for wearing his Hitler Youth uniform and clicking his heels. The teacher later apologized, presumably out of fear. ${ }^{52}$ Marta Hessler's and Gertrud Sombart's families were both anti-Nazi and described the fear of being caught opposing the party. ${ }^{53}$ Werner Hassel's father reportedly helped a Jewish friend pose as a non-Jew

\footnotetext{
${ }^{48}$ Maschmann. Account Rendered: A dossier on my former self. 1965. 40-41.

49 Johnson, and Reuband. What We Knew: Terror, Mass Murder and Everyday Life in Nazi Germany. 2006. 148.

${ }^{50}$ Maschmann. Account Rendered: A dossier on my former self. 1965. 54.

${ }^{51}$ Johnson, Eric A., and Karl-Heinz Reuband. What We Knew: Terror, Mass Murder and Everyday Life in Nazi Germany. Basic Books, 2006. 144-145.

52 Johnson and Reuband. What We Knew: Terror, Mass Murder and Everyday Life in Nazi Germany. 2006. 145.

${ }^{53}$ Johnson and Reuband. What We Knew: Terror, Mass Murder and Everyday Life in Nazi Germany. 2006. 141.
}

working in a local factory. ${ }^{54}$ Several of these Germans said their homes were monitored by the Gestapo and served as meeting places for like-minded individuals. Many of them also claim never to have given the Nazi salute, possibly in an attempt to vindicate themselves or in sincerity. ${ }^{55}$ Nevertheless, at least some Germans were not Nazi supporters, though they mostly kept their convictions to themselves.

In one such family, Hiltrud Kühnel's father was deemed "politically unreliable"; their home served as a meeting place for others who disagreed with the Nazis. She claims to have known all along that the concentration camps were meant for extermination. She even goes so far as to say, "... if someone says today that he had never known that [the concentration camps were extermination camps], it is absolutely not true." However, she goes on to say that she first received this information from the dissenters who frequented her home, including clergy. Her professor even openly discussed it when he told her class how he visited these camps to measure skulls. ${ }^{56}$ This, however, seems to be a generalization. Not everyone had anti-Nazi friends with whom to share such disquieting information. Ruth Hildebrand said that initially they believed the camps were for labor, but it "slowly leaked out" what their real purpose was, though without specific details. ${ }^{57}$ A local Nazi leader, Ernst Walters, said he did not know until he was passing through Thuringia and noticed an atrocious stench. The locals told him that it was the burning corpses from the nearby camp where soap was made from their bones. Walters also claimed that it was not dangerous to discuss the extermination of the Jews, and many did. According to these witnesses, the mass murder was common knowledge. But does knowing about a crime make one guilty of it? They did not themselves pull the trigger or pour in the gas, but does the fact that they may have been able to stop it make them culpable?

Though discrimination toward the Jews was obvious, many Germans claimed that they had no idea a genocide

\footnotetext{
${ }^{54}$ Johnson and Reuband. What We Knew: Terror, Mass Murder and Everyday Life in Nazi Germany. 2006. 181.

55 Johnson and Reuband. What We Knew: Terror, Mass Murder and Everyday Life in Nazi Germany. 2006.

${ }^{56}$ Johnson and Reuband. What We Knew: Terror, Mass Murder and Everyday Life in Nazi Germany. 2006. 186-189.

${ }^{57}$ Johnson, and Reuband. What We Knew: Terror, Mass Murder and Everyday Life in Nazi Germany. 2006. 194.
} 
was taking place. On March 30, 1933, Himmler announced the establishment of Dachau as a prison camp for communists, unionists, and political enemies. ${ }^{58}$ This cemented in the German mind that concentration camps were simply prisons. In the Berlin area, there were as many as 645 camps, all of them for forced labor. After the widespread dissent on the Euthanasia program, the Nazi government quickly learned that any sort of killing operation had to be kept under wraps. Almost all of the death camps were in Poland, while the labor camps that German citizens encountered were not. So, when they heard that Jews were being sent to concentration camps, they thought of a prison-like complex. ${ }^{59}$

Dr. T. H. told Primo Levi in a letter that he had never heard of "spontaneous outrage or aggression" towards Jews until after the war. ${ }^{60}$ Another letter from L. I. of Westphalia claimed that she had no idea of the death camps, despite living in the same region as Auschwitz. ${ }^{61}$ Werner Hassel was serving in the military at the time and asserted that the soldiers on the front "knew effectively nothing about the concentration camps and the mass murder of the Jews." Like others, he said they believed the camps were jails. ${ }^{62}$ Gertrud Sombart, a teenager in 1933, saw a group of Jewish prisoners, but "thought they were criminals. They looked like criminals." Sombart was among those who believed the camps were labor camps. ${ }^{63}$ Others, such as Hubert Lutz, say they hardly heard of concentration camps; for them it was "out of sight, out of mind." Lutz also said that parents were encouraged to shelter their children. ${ }^{64}$ This suggests that adults at the time had a firmer grasp on the true nature of the deportations than has been claimed.

Within the general population were the Christians, who proved to be influential before and during the Third Reich. While having minimal effect on the leadership of Nazi Germany, Christianity had a considerable impact

\footnotetext{
${ }^{58}$ Goldhagen. Hitler's Willing Executioners: Ordinary Germans and the Holocaust. 1997. 170.

${ }^{59}$ Goldhagen. Hitler's Willing Executioners: Ordinary Germans and the Holocaust. 1997. 171.

${ }^{60}$ Levi. The Drowned and the Saved. 1989. 176-177.

${ }^{61}$ Levi. The Drowned and the Saved. 1989. 181.

${ }^{62}$ Johnson, and Reuband. What We Knew: Terror, Mass Murder and Everyday Life in Nazi Germany. 2006. 181-182.

${ }^{63}$ Johnson, and Reuband. What We Knew: Terror, Mass Murder and Everyday Life in Nazi Germany. 2006. 162.

${ }^{64}$ Johnson, and Reuband. What We Knew: Terror, Mass Murder and Everyday Life in Nazi Germany. 2006. 147-148.
}

on those who regularly attended church. Bergen suggests that Christianity "[made] their [Nazi leaders'] commands comprehensible and tolerable to the rankand-file - the people who actively carried out the measures against the Jews as well as those who passively condoned their implementation." ${ }^{\circ 5}$ While it certainly played a role, it is important to remember that Christianity was one factor among many, including the economic crisis, widespread pre-existing antisemitism, and the effects of World War I. ${ }^{66}$

Goldhagen claims that Germany had a long history of antisemitic attitudes and that the Nazi era simply brought it to the forefront. He further states that this can be proved by looking at groups that would be the least disposed to exhibit such deadly prejudices, such as the Christians. ${ }^{67}$ On the contrary, a look at Church history shows that Christians were especially disposed to persecute Jews. The understanding of Judaism not so much as a religion but as a separate race was a well-established part of the day's political culture. ${ }^{68}$ Bergen describes the traditional Christian view of the Jew as "blind, stubborn, carnal, and perverse." This view had been cultivated by generations of the Church preaching such things in connection with the 'murder' of Jesus. ${ }^{69}$ The impact of this perception was widespread, as nearly ninety-five percent of the population was Christian, with approximately sixty-three percent Protestant and the rest Catholic. ${ }^{70}$ During the Weimar Republic, Goldhagen claims that seventy to eighty percent of pastors supported the German National People's Party. ${ }^{71}$

Antisemitism has existed in the church since nearly the beginning of Christianity. The Gospel of John, for example, includes verses that suggest the Jews are the

${ }^{65}$ Bergen, Doris L. 1994. "Catholics, Protestants, and Christian Antisemitism in Nazi Germany."

Central European History (Brill Academic Publishers) 27, no. 3: 329. Academic Search Premier, EBSCOhost (accessed October 15, 2017). 329.

${ }^{66}$ Bergen. Catholics, Protestants, and Christian Antisemitism in Nazi Germany. 1994. 330.

${ }^{67}$ Goldhagen. Hitler's Willing Executioners. 1997. 106.

${ }^{68}$ Goldhagen. Hitler's Willing Executioners. 1997. 106.

${ }^{69}$ Bergen. Catholics, Protestants, and Christian Antisemitism in Nazi Germany. 1994. 330.

${ }^{70}$ Bergen. Catholics, Protestants, and Christian Antisemitism in Nazi Germany. 1994. 330., Goldhagen. Hitler's Willing Executioners. 1997. 107.

${ }^{71}$ Goldhagen. Hitler's Willing Executioners. 1997. 107. 
children of the devil and blame them for the death of Jesus. ${ }^{72}$ Supersessionism, the theory that the Christian church replaced the Jews as the chosen people of God, was developed as early as the second century. This theory, along with and the idea of "total responsibility"that "all Jews from the first century onwards" are guilty of the murder of Jesus - laid the groundwork for Jewish persecution for centuries to come. ${ }^{73}$ In the fourth century alone, many church communities and rulers banned inter-religious marriages and condoned the destruction of synagogues. The Edict of Milan, which established toleration for Christians, revoked the same rights for Jews. The Council of Nicaea declared "let us have nothing in common with this odious people...." 74 The Crusades resulted in the deaths of hundreds of thousands of Jews, as did numerous pogroms through the centuries, all condoned by the church. Over the years Jews were exiled, forced into ghettos, and required to don badges declaring their faith. The idea of an international Jewish conspiracy first came from an essay written by a Jesuit priest that blamed the Jews for the French Revolution. Servius Nilus, a Russian Orthodox priest, first published the Protocols of the Elders of Zion. ${ }^{75}$

Martin Luther, the founder of the Protestant church, also contributed to the anti-Jewish sentiments of Christians in Nazi Germany. He initially was not against the Jews, but when they did not convert to his new brand of Christianity, he retaliated. In his book On the Jews and Their Lies, he refers to them as blind, stubborn, arrogant, and insists that the only thing one could learn from them is "how to misunderstand the divine commandments...." ${ }^{\prime 76}$ He claims everything they own was stolen through usury and accuses them of lying for thousands of years. Four hundred years before it would come true, Luther called for their removal from Germany: “...but then eject them forever from this country. For, as we

\footnotetext{
${ }^{72}$ John 8:42-44. In NIV foundation study Bible: New International Version. Grand Rapids, MI: Zondervan, 2015.

${ }^{73}$ Robinson, B. A. "Anti-Semitism in the Roman Catholic Church: 1 st to 20th Century CE."

Religious Tolerance. July 25, 2001. Accessed November 09, 2017.

${ }^{74}$ Robinson. "Anti-Semitism in the Roman Catholic Church: 1st to 20th Century CE." 2001.

${ }^{75}$ Robinson. "Anti-Semitism in the Roman Catholic Church: 1st to 20th Century CE." 2001.

${ }^{76}$ Anti-Semitism: Martin Luther - "The Jews \& Their Lies"." Jewish Virtual Library. 2017. Accessed November 09, 2017.
}

have heard, God's anger with them is so intense that gentle mercy will only tend to make them worse and worse, while sharp mercy will reform them but little. Therefore, in any case, away with them!" Another quote precisely portrays the Nazi understanding of the Jews a parasitic people: "Over and above that we let them get rich on our sweat and blood, while we remain poor and they suck the marrow from our bones." 77 Luther called for Christians to avoid acting in any amiable way towards Jews and likens them to the devil himself, a charge many Christians in the Reich took to heart. He finally made numerous recommendations that were put into practice under Hitler: their synagogues and homes burnt, their religious writings destroyed, the practice of their faith carry the penalty of death, and themselves put to forced labor. ${ }^{78}$ These ideas persisted in the church until the Nazi era, permeating writings, sermons, and the minds of ordinary Germans.

Antisemitism became an increasingly frequent topic in Christian writings during the twenties, correlating with the increasingly antisemitic "political atmosphere" and the rise of National Socialism. ${ }^{79}$ Since the majority of Germans were involved with a church, these Christian papers reached a wide audience. For example, the antisemitic Protestant newspaper, the Sonntagsblätt, reached an estimated 5.4 million people, thereby contribute to the shaping of the antisemitic attitude of Protestant Christians in Germany. ${ }^{80}$

There are many examples of church leadership, both Catholic and Protestant, that encouraged Nazism and antisemitism. In a letter following the April 1933 boycott, Bishop Otto Dibelius, a prominent pastor, wrote that he had "always [been] an antisemite," and that "one cannot fail to appreciate that in all of the corrosive manifestations of modern civilization Jewry plays a leading role." He advocated for a ban on all Jewish immigration and hoped this would lead to the Jews dying out in Germany. ${ }^{81}$ Another bishop, Martin Sasse, praised Kristallnacht and the destruction of synagogues. ${ }^{82}$ Even Martin Niemöller, an anti-Nazi pastor, exhibited rampant antisemitic tendencies. ${ }^{83}$ In a 1935 sermon he said,

\footnotetext{
${ }^{77}$ Anti-Semitism:MartinLuther-"TheJews\&TheirLies"."2017.

${ }^{78}$ Anti-Semitism:MartinLuther-"TheJews\&TheirLies"."2017.

${ }^{79}$ Goldhagen. Hitler's Willing Executioners. 1997. 107.

${ }^{80}$ Goldhagen. Hitler's Willing Executioners. 1997. 107.

${ }^{81}$ Goldhagen. Hitler's Willing Executioners. 1997. 108.

${ }^{82}$ Goldhagen. Hitler's Willing Executioners. 1997. 110.

${ }^{83}$ Goldhagen. Hitler's Willing Executioners. 1997. 112.
} 
"What, then, is the real reason for this manifest penal judgment which continues in force century after century? Dearly beloved, the answer is evident, the Jews have caused the crucifixion of God's Christ... They bear the curse, and because they rejected the forgiveness, they drag with them as a fearsome burden the unforgiven blood-guilt of their fathers." 84 In a sermon given by Cardinal Faulhaber in 1933 he stated:

After the death of Christ, Israel was dismissed from the service of the Revelation. She had not known the time of her visitation. She had repudiated and rejected the Lord's Anointed, had driven Him out of the city and nailed Him to the cross. Then the veil of the Temple was rent, and with it the covenant between the Lord and his people. The daughters of Sion [sic] received the bill of divorce.... ${ }^{85}$

Faulhaber's words clearly emphasized that the Jews had been condemned by God and carried the implication that they were a villainous people. Sermons such as these were commonly proclaimed from the pulpit, highlighting the alleged betrayal of Jesus and often outright supporting the Nazis' opposition to the Jews. One Catholic sermon was considered so pro-Nazi that a group of people left during it ${ }^{86}$ In 1939 the Protestant Bishop of Bremen released the "first new, explicitly antisemitic 'translation' of the Gospel of John." ${ }^{\text {"7 }}$

Even those Church leaders who opposed Nazism were not innocent of antisemitism. For example, Archbishop Gröber preached that Jesus was not Aryan, but qualified this statement by emphasizing that only his mother was Jewish, and that his father was technically the Holy Spirit. A similar trend can be observed when numerous Catholic bishops spoke out against legislation that would require Aryans to divorce their Jewish spouses, but softened their attack by claiming that their objections were not out of a "lack of love for the German nationality or underestimation of the harmful Jewish in-

\footnotetext{
${ }^{84}$ Bergen. Catholics, Protestants, and Christian Antisemitism in Nazi Germany. 1994. 332.

${ }^{85}$ Bergen. Catholics, Protestants, and Christian Antisemitism in Nazi Germany. 1994. 332.

${ }^{86}$ Bergen. Catholics, Protestants, and Christian Antisemitism in Nazi Germany. 1994. 334.

${ }^{87}$ Bergen. Catholics, Protestants, and Christian Antisemitism in Nazi Germany. 1994. 334.
}

fluences on German culture and national interest." ${ }^{88}$ Furthermore, historian Uriel Tal showed how some groups such as Lutherans were against National Socialism and drew connections between them and the Jews. For example, Niebergall, a professor of pastoral theology, "taught both Nazis and Jews rejected Jesus as savior and set up political messianism in his place." Some argued that the Nazi characteristics of "materialism... self-sufficiency...self-righteousness...nationalistic ethnicity... [and] resistance to salvation through faith in Christ" was rooted in Judaism. They believed that both Judaism and National Socialism "destroyed the traditional authority of family, society, economy, and politics; [and that] both...defined themselves by blood in ways that lead to chauvinistic racism." ${ }^{89}$ Still there were those who fought the radical antisemitism that consumed the nation, such as Bernhard Lichtenberg and Dietrich Bonhoeffer. ${ }^{90} \mathrm{~A}$ pastor near Bamburg gave a sermon so "aggressively pro-Nazi" that nearly thirty people got up and left. He said in response, "let them go, they're nothing but Jewservers." $" 91$

Ever since the Reformation, the Protestant and Catholic churches have maintained an icy relationship. Nazi officials criticized both for their devotion to the church and saw this and the Catholic-Protestant division as destructive to the Reich. ${ }^{92}$ During the Third Reich, each frequently accused the other of having traits the Nazis deemed Jewish; Catholics defined Protestantism by "godlessness, immorality, and liberalism," while Protestants called Catholics "dogmatic, divisive, and international." $" 93$

Because of these divisions, the Nazi government did not encourage Christianiy, but did exploit the antisemitism endemic in the Church. Nazi leadership accused Christianity of being not only "un-German" but also

\footnotetext{
${ }^{88}$ Bergen. Catholics, Protestants, and Christian Antisemitism in Nazi Germany. 1994. 334.

${ }^{89}$ Bergen. Catholics, Protestants, and Christian Antisemitism in Nazi Germany. 1994. 335.

${ }^{90}$ Bergen. Catholics, Protestants, and Christian Antisemitism in Nazi Germany. 1994. 346.

${ }^{91}$ Bergen. Catholics, Protestants, and Christian Antisemitism in Nazi Germany. 1994. 334.

${ }^{92}$ Bergen. Catholics, Protestants, and Christian Antisemitism in Nazi Germany. 1994. 341.

${ }^{93}$ Bergen. Catholics, Protestants, and Christian Antisemitism in Nazi Germany. 1994. 336.
} 
Jewish in nature. Furthermore, Catholics' loyalty to Germany was questioned and they were accused of being an international body, similar to the Jews. The state made it clear that "only an explicitly antisemitic Christianity belonged in the Third Reich." ${ }^{94}$ Many Christians did not wish to be on the Nazis' target list, and therefore sought to prove their commitment to the Reich and antisemitism. One specifically pro-Nazi group, the "German Christians," cited Martin Luther's anti-Jewish essay "Against the Jews and Their Lies" as justification. Some sermons included quotes and themes like "No one loves his Fatherland like a Catholic priest," and "Everything for Germany, and Germany for Christ." The Church's efforts to prove itself loyal "legitimized and reinforced" antisemitism for the general public, leading them to believe it was morally acceptable. ${ }^{95}$

Another effort to combat Nazi allegations sought to unite Catholics and Protestants, not under the banner of Christianity, but under antisemitism. The "German Christians" was one of the groups involved, and they tried to add "One Faith" to the phrase "One Volk, One Reich, One Führer." The faith they wanted was "uniquely Germanic, stridently warlike, and explicitly anti-Jewish." At one of their events, a speaker said that it didn't matter if you were Catholic or Protestant "as long as [you believed] in an "eternal Germany." former Catholic priest who joined the "German Christians" gave an advent sermon dressed in a militaristic, Nazi-esque uniform. During the sermon, he told the congregation that Jesus "did not have a home in the Catholic church because it has a pope," nor in the Prot- " estant church "because it has a paper pope, the Bible." He contended, "only in the sanctuary of a racially pure German church...could true Christianity be at home." 97 However, these efforts failed to bring the two together. The divisions between Catholics and Protestants were too strong and the movement too hampered by faction and infighting. ${ }^{98}$

\footnotetext{
${ }^{94}$ Bergen. Catholics, Protestants, and Christian Antisemitism in Nazi Germany. 1994. 333.

${ }^{95}$ Bergen. Catholics, Protestants, and Christian Antisemitism in Nazi Germany. 1994. 333.

${ }^{96}$ Bergen. Catholics, Protestants, and Christian Antisemitism in Nazi Germany. 1994. 336.

${ }^{97}$ Bergen. Catholics, Protestants, and Christian Antisemitism in Nazi Germany. 1994. 338.

${ }^{98}$ Bergen. Catholics, Protestants, and Christian Antisemitism in Nazi Germany. 1994. 338-340.
}

Bergen says that it is "tempting to suggest that the churches had little option, given the 'totalitarian' nature of the 'Nazi police state' and their own desperate fight to survive in the face of Nazism's anti-Christian onslaught." However, Catholics fought the removal of crucifixes from schools in Bavaria, some openly bemoaned the opposition to Christianity in the Reich, and pro-Nazi Christians even protested the Euthanasia program. In a letter to authorities, one Christian countered the argument that Euthanasia was to make room for pilots with nervous illnesses by pointing to the many millions of Jews who are still in the country. "Why do these dregs of society still live while our sick are simply being murdered?" Furthermore, Christians enabled the Nazis in seeking Jews by providing genealogies and baptism records. Though the Nazis insisted the Jews were a racial issue, they "fell back on religious affiliations - of parents and grandparents - as the only practical criterion for defining who was a Jew."

What opposition there was to the provision of these records focused on the "logistical challenges" of analyzing so many documents. ${ }^{99}$ In the aftermath of the Holocaust, many church leaders and Christians expressed remorse or shame, while others struggled to recognize their lack of action in defense of the Jews and others. Albert Schweitzer wrote in the preface to Rolf Hochhuth's play, The Deputy, "...for our failure made us all participants in the guilt of those days. After all, the failure was not that of the Catholic Church alone, but of the Protestant Church as well." ${ }^{100}$ In 1946 Pastor Hermann Diem said, "By preparing countless certificates of Aryan ancestry we aided in the racist conceit." ${ }^{101}$ Because of their preoccupation with this pseudo-Christianity, they ignored and even endorsed the plight of the Jews. This made things even harder for victims and reinforced the idea that Christians, in general, were not to be trusted. ${ }^{102}$ Many Holocaust survivors today see no difference between Catholics and Protestants; their shared antisemitism

\footnotetext{
${ }^{99}$ Bergen. Catholics, Protestants, and Christian Antisemitism in Nazi Germany. 1994. 346.

${ }^{100}$ Bergen. Catholics, Protestants, and Christian Antisemitism in Nazi Germany. 1994. 346.

${ }^{101}$ Bergen. Catholics, Protestants, and Christian Antisemitism in Nazi Germany. 1994. 346.

102 Bergen. Catholics, Protestants, and Christian Antisemitism in Nazi Germany. 1994. 345.
} 
was enough to render their differences "indistinguishable in the eyes of the victim." 103

As previously discussed, blatant antisemitism revealed itself early on in the Third Reich. Many towns began forbidding Jews to enter public areas even before the Nuremberg Laws or federal laws required it. ${ }^{104}$ Goldhagen cites many reports of widespread and frequent antisemitic attacks. One of his most poignant points is the nearly non-existent public objection to the persecution of the Jewish community. Other moral transgressions were publicly and sometimes loudly protested, such as the treatment of Poles and Slavs and the Euthanasia program. Many ironically argued that the Poles "were people too" and thus had the right to humane treatment. But no such argument was heard for the thousands of Jewish men, women, and children being gassed in concentration camps. The outrage against the Euthanasia program was so great that the government took greater lengths to conceal it and eventually halted it entirely. Only one public protest in favor of the Jews occurred: German women whose Jewish husbands were taken in Berlin joined together to save their husbands. Their activism resulted in the release of 6,000 men. These three examples, Goldhagen claims, prove that "Germans 1) recognized [what] was wrong, 2) expressed their views 3) openly protested it, 4) with no consequences, [and] 5) succeeded." If the Germans had cared about the Jews, there would not have been a Holocaust, or at the very least not what did exist would not have been on the same scale. ${ }^{105}$ This reasoning makes arguments giving Germans the benefit of the doubt seem futile. However, such reasoning neglects to consider that German fear for their livelihood and lives was a reality in the Nazi era.

The Allies seem to have assumed that the German people were collectively guilty for the Holocaust. For example, the inhabitants of towns near camps were taken to the camps to see first-hand what they had ignored and passively supported. James Stern of Nauheim saw posters all over the town with images of the dead which read "Who is guilty?" Shortly thereafter, new posters reading, "The town is guilty! You are guilty!" replaced

\footnotetext{
${ }^{103}$ Bergen. Catholics, Protestants, and Christian Antisemitism in Nazi Germany. 1994. 341.

${ }^{104}$ Goldhagen. Hitler's Willing Executioners: Ordinary Germans and the Holocaust. 1997. 96.

${ }^{105}$ Goldhagen. Hitler's Willing Executioners: Ordinary Germans and the Holocaust. 1997. 117-119.
}

the previous ones. ${ }^{106}$ In addition, the Allies issued a directive that defined who was guilty and to what extent based on the level of their involvement. The directive included major offenders, offenders, lesser offenders, followers, and persons exonerated and states that those in the latter category are apart from the other four and have proved themselves innocent before a jury. ${ }^{107}$ This implies that the Allies believed nearly the entire German population was responsible for what had happened. However, as the United States set up tribunals to try those in the first four groups and required them all to register, they quickly found that there were too many "chargeable" people to try every one of them, effectively $27 \%$ of the adult population. A series of amnesties were thus required to make the load more manageable. ${ }^{108}$

One issue with collective guilt is that assuming that all Germans were guilty of killing six million Jews is a generalization. Without further clarification, it includes children, anti-Nazis, and even victims. FitzGibbon further questions whether it is legally or morally right to prosecute people solely for being a Nazi or not speaking up against them. ${ }^{109}$ Students who witnessed bullying are not suspended along with the bully, so why should a German bystander likewise be held responsible? However, this is a delicate line to walk, and the systematic murder of millions of people is hardly comparable to schoolyard bullying. Faced with this conundrum, the Allies instituted amnesties for several groups in Germany. One stated that anyone born on or after January 1, 1919 was cleared of responsibility; others declared that only those who were part of a specific organization were guilty. ${ }^{110}$

Additionally, Hitler and his government learned from the Euthanasia program that they would have to take careful measures to keep the death camps from German view. Many Germans themselves, such as Dr. T. H., claim they were completely unaware that the deported Jews were being murdered. He claimed to have been tricked into following "a criminal and a traitor." He goes on to say, "And in any case, no guilt can certainly be attributed to the betrayed: the traitor alone is guilty."

\footnotetext{
${ }^{106}$ FitzGibbon, Constantine. Denazification. New York: Norton, 1969. 95.

${ }^{107}$ FitzGibbon, Constantine. Denazification. New York: Norton, 1969. 109-114.

${ }^{108}$ FitzGibbon. Denazification. 1969. 131-132.

${ }^{109}$ FitzGibbon. Denazification. 1969. 97-99.

${ }^{110}$ FitzGibbon. Denazification. 1969. 132, 161.
} 
Another woman attempted to clear her husband by saying, "What could they do about it, our poor soldiers, if they gave them those orders? When my husband came on furlough from Poland, he told me: 'Almost all we did was shoot Jews, shoot Jews all the time. My arm hurt from so much shooting,' But what was he supposed to do, if they had given him those orders?"111

On one hand, these arguments are useless. Men have their own free will and could have refused to take part in the killing. Naturally, there may have been consequencs, but only at the cost of freeing their conscience and doing the right thing. Moreover, Hitler's Mein Kampf, published in 1925, is explicit about his opinions on Jews. One of a plethora of examples is, "When...I recognized the Jew as the cold-hearted, shameless, and calculating director of this revolting vice traffic scum...." Hitler even implied a call to action for Aryans to "fight the struggle for existence by their own labor." 112 It has been clear from the beginning what Hitler's and the Nazis' views were, so how can anyone say their complicity is not their fault? However, on the other hand, there were real consequences for disloyalty that impacted not only the individual but their family as well.

Despite claims that the Germans had nothing to fear for resisting the Nazi government, others provide irrefutable evidence that fear was, in fact, a reality. The propaganda campaigns and Nazi take-over of German culture cut through all strata of class and culture and "punctuated the everyday lives of ordinary Germans. The Nazi leadership, which hoped to dominate Germany through political power and terror, but also by winning the 'hearts and minds' of the population, utilized this coordination of culture, high and low, to influence at the most basic level the lives and actions of its citizens." 113 Beginning in the 1920s, the Sturmabteilungen (Storm Troopers, or SA) and the Schutzstaffel (SS) were responsible for physically intimidating anyone who obstructed or opposed the National Socialists. With Hitler's rise to power, they were given the authority to "beat or kill persons they deemed to be opponents." "114 The Reich-

\footnotetext{
${ }^{111}$ Levi. The Drowned and the Saved. 1989. 176-177.

${ }^{112}$ Hitler, Adolf. Mein Kampf. Translated by Ralph Manheim. New York: Houghton Mifflin Company, 1971. 59, 150 .

113 " Culture in the Third Reich: Disseminating the Nazi Worldview." United States Holocaust Memorial Museum. Accessed November 02, 2017.

114 "Nazi Terror Begins." United States Holocaust Memorial Museum. Accessed November 15, 2017.
}

stag Fire Decree placed the German government in a permanent state of emergency and formally suspended the freedoms of speech, press, assembly, habeas corpus, and the need for a warrant or reasonable cause before entering and searching one's home. The Geheime Staatspolizei (the secret police otherwise known as the Gestapo) was established shortly thereafter, charged with the task of seeking out those who opposed the state and its policies. ${ }^{115}$ These organizations, along with the civil administration, army, and the Party itself, created an anxious climate that surrounded the German citizenry and permeated daily life. ${ }^{116}$

The clearest example of this fear is the concept of Sippenhaft, which asserts that if an individual is guilty of a crime, the family of the guilty party is also liable. Sippenhaft implied that criminal behavior was a matter of blood and necessitated the punishment or obliteration of those with criminal blood, an idea that suits Nazi racial ideology. ${ }^{117}$ Himmler believed that it had been an Aryan tradition for centuries, saying, "When they placed a family under the ban and declared it outlawed or when there was a blood feud in the family, they were utterly consistent.... This man has committed treason; his blood is bad; there is traitor's blood in him; that must be wiped out. And in the blood feud the entire clan was wiped out down to the last member." 118 Punishment had many manifestations; arrest, the loss of a job or future employment opportunities, reassignment to a penal battalion, and in some cases, death. Once Sippenhaft was established, the "fear of [its] application rather than implementation [was what] mattered." 119

115 "Nazi Terror Begins." United States Holocaust Memorial Museum. Accessed November 15, 2017.

${ }^{116}$ Loeffel, Robert. "The Sinews of the Modern Terror State: An Analysis of the Role and Importance of Family Punishment in Nazi Germany* The Sinews of the Modern Terror State: An Analysis of the Role and Importance of Family Punishment in Nazi Germany." Australian Journal of Politics \& History 58, no. 3 (September 2012): 380-393. Academic Search Premier, EBSCOhost (accessed November 15, 2017). 380.

${ }^{117}$ Loeffel. "The Sinews of the Modern Terror State: An Analysis of the Role and Importance of Family Punishment in Nazi Germany. September 2012. 381.

118 "Sippenhaft." Jewish Virtual Library. 2017. Accessed November 16, 2017.

${ }^{119}$ Loeffel. "The Sinews of the Modern Terror State: An Analysis of the Role and Importance of Family Punishment in Nazi Germany. September 2012. 381. 
Its use in Nazi Germany began in 1933 and targeted communists and their families. Albert Walter, a communist sympathizer, was arrested, and despite torture refused to talk. His mother was then arrested, and Walter was told that unless he gave in, she would be tortured and killed, a threat which lead him to become an informant. Union leader and Social Democrat (SPD) member Johannes Grote was first fired and then arrested along with his wife for their alleged disloyalty to the Nazi Party. These are merely two examples, and such cases were published in the papers. A June 18, 1933, article in the SPD affiliated newspaper Neuer Worwärts reported that "wives and children of fugitive husbands were being made hostages."120

The Nazi government made no attempt to hide these arrests but, in fact, broadcasted them even in foreign papers. Philip Scheidemann, a former chancellor living in exile, had been writing against the regime in the New York Times. As reported by the Völkische Beobachter in July 1933, five of his family members were arrested and consequently sent to a concentration camp. The following December, the German government posted a declaration in the Times stating that "in the future relentless measures will be taken if fugitive Marxists should attempt to propagandize against Germany." 121 Such vague language also served to perpetuate the fear and uncertainty of what exactly 'relentless measures' meant. Other examples include Richard Krebs, whose wife died in custody after his release, and General von Schleicher who was murdered with his wife in the Night of the Long Knives. The assassination of Frau Schleicher was not only "openly admitted" but "specifically mentioned" by the press. ${ }^{122}$ This period introduced extralegal and vague policy to Germans.

After the initial cleaning-house of political opposition between early 1933 and the summer of 1934, Sippenhaft shifted to more subtle means. The threat became one with more social and political ramifications. For example, the German housemaid of Victor Klemperer,

\footnotetext{
${ }^{120}$ Loeffel. "The Sinews of the Modern Terror State: An Analysis of the Role and Importance of Family Punishment in Nazi Germany. September 2012. 382.

${ }^{121}$ Loeffel. "The Sinews of the Modern Terror State: An Analysis of the Role and Importance of Family Punishment in Nazi Germany. September 2012. 383.

${ }^{122}$ Loeffel. "The Sinews of the Modern Terror State: An Analysis of the Role and Importance of Family Punishment in Nazi Germany. September 2012. 383-384.
}

a German-Jew, was "intimidated out of working for him by threats against her family." ${ }^{123}$ Furthermore, the Reich Minister of the Interior, Wilhelm Frick, began publishing the first of 359 lists revoking the citizenship and property of those listed. These lists quickly began including the names of relatives of known 'enemies of the state.' This showed the German public that "families were being barred as citizens en masse because of the crime of one of their relatives." 124 The public understood that the only grounds needed for arrest was the alleged crime of a family member. Denunciations also fueled this fear. The mere suggestion of anti-Nazi attitudes to the Gestapo could be enough to jeopardize the safety of one's family. ${ }^{125}$

After the German defeat at Stalingrad, Sippenhaft saw a resurgence and intensification. It also became necessary for the accusing party to provide actual charges against an individual to arrest them. The Scholl siblings, for instance, were involved with the White Rose resistance. In order to arrest their father, he was accused of listening to foreign radio broadcasts with weak testimony and was imprisoned for eighteen months. Elfrieda Scholz, the sister of the author of the very un-Nazi novel All Quiet on the Western Front, was denounced by two customers of her shop for "defeatism" on "flimsy evidence." Judge Roland Freisler hinted that her true guilt was that of her brother's when he said, "unfortunately your brother has escaped us-you, however, will not escape us." She was executed on December 16, 1943. ${ }^{126}$

The increased intensity of Sippenhaft punishment and enforcement was especially pronounced in the Wehrmacht. A 1938 pamphlet from the High Command of the Armed Forces stated that "traitors will bring misfortune and ruin upon their families." ${ }^{127}$ Threatening sol-

\footnotetext{
${ }^{123}$ Loeffel. "The Sinews of the Modern Terror State: An Analysis of the Role and Importance of Family Punishment in Nazi Germany. September 2012. 384.

${ }^{124}$ Loeffel. "The Sinews of the Modern Terror State: An Analysis of the Role and Importance of Family Punishment in Nazi Germany. September 2012. 385.

125 "Nazi Terror Begins." 2017.

${ }^{126}$ Loeffel. "The Sinews of the Modern Terror State: An Analysis of the Role and Importance of Family Punishment in Nazi Germany. September 2012. 385.

${ }^{127}$ Loeffel. "The Sinews of the Modern Terror State: An Analysis of the Role and Importance of Family Punishment in Nazi Germany. September 2012. 386.
} 
diers' families was a tool utilized by the Wehrmacht to prevent desertion and cowardice in battle. The severity of the punishments for this brand of Sippenhaft is evident in the case of Wenzeslaus Leiss. During an investigation for alleged desertion, it became known his family had a Polish background and his brother was involved in a local communist group. For this, five of his relatives, including his two-year-old daughter, were executed. ${ }^{128}$

Sippenhaft further intensified following the July 29 , 1944, attempted assassination of Hitler. The families of all who were involved in the plot were arrested, some died of maltreatment, others committed suicide, and still others survived the war. A children's camp was established to hold the offspring of the conspirators. The older sons were forced into the army or transferred to units on the front, where many of them died, such as those of Henning von Tresckow and General Erich Fellgiebel. ${ }^{129}$ One woman wrote to her brother on the Italian front, "nowadays one always thinks the worst everywhere, as happened yesterday when a man of the Party came to us. I just didn't dare ask what he wanted...." ${ }^{130}$ As more families were arrested, the reality that they could be next became clearer.

Until this point, there had been no specific language explaining what constituted Sippenhaft. This changed with a directive issued by Field Marshall Wilhelm Keitel on November 19, 1944. The process he outlined began with a soldier accused of desertion; a court-martial would be conducted on the spot, and if he was guilty, he faced immediate death by firing squad. His family would lose their property and either be imprisoned or executed. This directive was announced to both the troops and the public. ${ }^{131}$

The vague nature of Sippenhaft and its decentralized, widespread use created and perpetuated a climate of fear. Many assumed that those arrested were automatically

\footnotetext{
${ }^{128}$ Loeffel. "The Sinews of the Modern Terror State: An Analysis of the Role and Importance of Family Punishment in Nazi Germany. September 2012. 386.

${ }^{129}$ Loeffel. "The Sinews of the Modern Terror State: An Analysis of the Role and Importance of Family Punishment in Nazi Germany. September 2012. 388.

${ }^{130}$ Loeffel. "The Sinews of the Modern Terror State: An Analysis of the Role and Importance of Family Punishment in Nazi Germany. September 2012. 390.

${ }^{131}$ Loeffel. "The Sinews of the Modern Terror State: An Analysis of the Role and Importance of Family Punishment in Nazi Germany. September 2012. 390.
}

killed, causing their perception to be one of life or death. These measures began as ones reserved for the "non-believer" in Nazism, but as the war turned sour more and more lost faith in the Reich, it brought the threat even closer to home. ${ }^{132}$ "The main purpose of this form of punishment," argues Loeffel, "was the threat itself, disseminated successfully through the rumor mill." It would be difficult to argue that fear instilled by Sippenhaft did not play a role in suppressing resistance amongst Germans at large.

The line between those responsible for the Holocaust and those not is a hazy and blurred one. We cannot know with certainty each German's thoughts, or what they knew and when they knew it. However, how could one have not known that something sinister was happening? Low had this to say in regard to those who espoused antisemitism:

Is it justified to point the finger of accusation at all those who...have expressed anti-Semitic feelings and thoughts? No doubt many of the German Jew-haters of earlier times might have recoiled from the mass murder of the Jews the Nazis later committed.... On the other hand, it seems only fair to hold each man responsible for what he said, wrote, and recommended. ${ }^{133}$

In light of this, is it justified to hold responsible those who stood by silently while their Jewish neighbors were herded toward death? Many Germans expressed shock and horror upon learning the gruesome details, but was Hitler's antisemitic eliminationist agenda not clear? The greater German public at least knew that the Jews were vanishing, and despite evidence that the ability to come together and oppose genocide existed, they turned off their minds to anything that made them uncomfortable. But, this they had to do to cope with their inaction due to the fear disseminated by threats like that of Sippenhaft. It is too simple and too harsh to judge the Germans this way.

\footnotetext{
${ }^{132}$ Loeffel. "The Sinews of the Modern Terror State: An Analysis of the Role and Importance of Family Punishment in Nazi Germany. September 2012. 392-393.

${ }^{133}$ Low. Jews in the Eyes of the Germans. 1979. 414.
} 
In conclusion, clearly those who were actively involved in the killing were guilty, were subject to legal prosecution and ought to have been tried, as many were. Those who risked themselves to protect and help Jews, the 'Righteous Among the Nations,' can naturally be excused. But the question of the rest of the Germans is more complicated. As Dresler-Hawke said, “... [it was] no longer a matter of a few guilty individuals - a whole nation stood accused ...." They could be legally prosecuted first because it was a moral issue and second because of the sheer volume of cases; it would simply have been impractical. The amnesty for those born in 1919 and after drew a clear line between guilty and innocent, but they would have been 26 by the end of the war, and many, such as Maschmann, were involved in Nazi organizations. There is always a moral obligation to do what is right. However, the climate of fear that settled in Germany complicated that obligation. Each German, if not explicitly Nazi, had to choose whether to risk their family for the lives of others. The long history of religious and secular antisemitism, coupled with the propaganda telling them what to think, obscured moral responsibility. Those who still saw through this were further silenced by Sippenhaft, leaving only the few 'Righteous' who stood against the regime. The simplest answer is that the average German was legally innocet, but morally responsible for the deaths of six million Jewish men, women, and children. In hindsight, it easy to make such a claim as this, but one must remember that it is impossible to fully understand the rationale of ordinary Germans that made the Holocaust possible.

\section{Bibliography}

Anti-Semitism: Martin Luther - "The Jews \& Their Lies." Jewish Virtual Library. 2017. Accessed November 09, 2017.

Bergen, Doris L. 1994. "Catholics, Protestants, and Christian Antisemitism in Nazi Germany." Central European History (Brill Academic Publishers) 27, no. 3: 329. Academic Search Premier, EBSCOhost (accessed October 15, 2017).

Browning, Christopher. "Afterward," Ordinary Men. New York: Harper Collins, 1998.

"Culture in the Third Reich: Disseminating the Nazi World view." United States Holocaust Memorial Museum. Accessed November 02, 2017.

Dresler-Hawke, Emma. "Reconstructing the Past and Attributing the Responsibility for Holocaust." Social Behavior
\& Personality: An International Journal 33, no. 2 (March 2005): 133-147. Academic Search Premier, EBSCOhost (accessed April 4, 2017).

FitzGibbon, Constantine. Denazification. New York: Norton, 1969.

Goldhagen, Daniel Jonah. Hitler's Willing Executioners: Ordinary Germans and the Holocaust. New York: Vintage Books, 1997.

Hitler, Adolf. Mein Kampf. Translated by Ralph Manheim. New York: Houghton Mifflin Company, 1971.

John 8:42-44. In NIV Foundation Study Bible: New International Version. Grand Rapids, MI: Zondervan, 2015.

Johnson, Eric A., and Karl-Heinz Reuband. What We Knew: Terror, Mass Murder and Everyday Life in Nazi Germany. Basic Books, 2006.

Levi, Primo. The Drowned and the Saved. Translated by Raymond Rosenthal. New York: Random House, Inc., 1989.

Loeffel, Robert. "The Sinews of the Modern Terror State: An Analysis of the Role and Importance of Family Punishment in Nazi Germany* The Sinews of the Modern Terror State: An Analysis of the Role and Importance of Family Punishment in Nazi Germany." Australian Journal of Politics \& History 58, no. 3 (September 2012): 380-393. Academic Search Premier, EBSCOhost (accessed November 15, 2017).

Low, Alfred D. Jews in the Eyes of the Germans. Philadelphia, PA: Institute for the Study of Human Issues, 1979.

Maschmann, Melita. Account Rendered: A Dossier on My Former Self. Translated by Geoffrey Strachan. London: Abelard-Schuman, 1965.

"Nazi Terror Begins.” United States Holocaust Memorial Museum. Accessed November 15, 2017.

Panayi, Panikos. Life and Death in a German Town: Osna brück from the Weimar Republic to World War II and Beyond. I.B Tauris, 2007.

"Primary Sources: Weimar Society." Facing History and Ourselves. 2017. Accessed November 03, 2017.

Robinson, B. A. "Anti-Semitism in the Roman Catholic Church: 1st to 20th Century CE." Religious Tolerance. July 25, 2001. Accessed November 09, 2017.

"Sippenhaft." Jewish Virtual Library. 2017. Accessed November 16, 2017.

The Holocaust Chronicle. Publications International, Ltd., 2000.

Vogt, Hannah. The Burden of Guilt: A Short History of Germany, 1914-1945. New York: Oxford University Press, 1964.

Zimmerman, Andrew. "Anti-Semitism as Skill: Rudolf Virchow's Schulstatistik and the Racial Composition of Germany." Central European History (Brill Academic Publishers) 32, no. 4 (December 1999): 409. Academic Search Premier, EBSCOhost (accessed October 30, 2017). 